\title{
Indeks Subyek
}

A

anak-anak, 141

Android, 90, 95

animasi

$2 \mathrm{D}, 141,143,149,150$

$3 \mathrm{D}, 51,52,53,54,56,66$

augmented reality, 97, 100, 102, 103, 104,

$109,111,113,114,116,117,118,121,122$,

$126,127,128$

\section{B}

battle, 87

C

collectivity, 67

$\mathbf{E}$

edukasi, 131

G

game, 97, 99, 100, 101, 102, 103, 104, 105,

106, 108, 109, 111, 112, 87, 88, 89, 90, 91,

94

board, 1, 4, 5, 6, 7, 8

memory card, 11

portal virtual, 113

studies, 70

video, 89, 129, 130, 131, 132, 133, 134,

135, 136, 137, 138, 139

Global Positioning System, 100

H

history, 11, 12

I

individualitas, 67, 68, 69, 70, 71, 72, 74, 75, 82

$\mathbf{K}$

kolam renang, 141, 143, 149

kolektivitas, 67, 68, 69, 70, 71, 73, 74, 75, 82

komedi, 51
$\mathbf{L}$

literasi, 27, 29, 30

location based, 97, 100, 102, 103, 111

\section{M}

Malang, 1, 2, 3, 10

markerless tracking, 113, 117

media

belajar, 129, 139

education, 1

edukasi, $1,7,8,10$

promosi, 97, 99, 101, 102, 103, 104, 107, 111,112

mobile, 90

Mobile

PlayerUnknown's Battlegrounds (PUBG), $67,69,70,75$

Monumen Tugu Pahlawan, 113, 115, 116, 119, $120,121,126,127$

moralitas, 129, 139

\section{$\mathbf{P}$}

pemain

gim, 67, 69, 70, 75, 79, 80, 81, 82

persahabatan, $51,52,53,66$

pertempuran, 87, 88, 89, 94

player

game, 67

produksi, 141, 145, 148

projection mapping, 27, 36, 40, 41

pop-up, 27, 40, 48

prototyping, 11, 12, 13, 14, 17, 25

PUBG Mobile, 67, 69, 75, 76, 78, 79, 80, 81, 82

S

sejarah, 11, 12, 13, 21, 25

perjuangan, $87,88,94$

$\mathbf{T}$

testing

black box, 11, 12, 21

Topeng 
Indeks Subyek

Malangan, 1, 2, 3, 6, 7, 8, 9, 10

trailer

book, 27, 29, 30, 31, 32, 33, 34, 38, 39, 40,

$42,44,45,46,47,48,49$

trauma, 141, 142, 143

Unity, 11, 12, 14, 25

V

virtual, 100, 113, 114, 118 